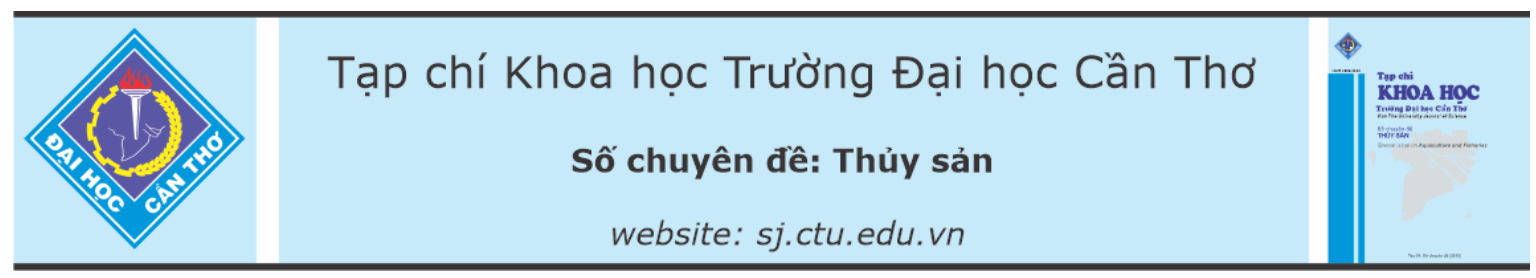

DOI:10.22144/ctu.jvn.2021.058

\title{
ẢNH HƯởNG CỦA MậT ĐỘ THẢ GIỐNG LÊN HIỆU QUẢ NUÔI TÔM CÀNG XANH (Macrobrachium rosenbergii) XEN CANH VỚI LÚA Ở VÙNG NƯớC Lợ
}

\author{
Võ Hoàng Liêm Đức Tâm*, Dương Nhựt Long, Nguyễn Thị Ngọc Anh, Trần Ngọc Hải và \\ Lam Mỹ Lan
}

Khoa Thủy sản, Truờng Đại học Cần Tho

*Nguoòi chịu trách nhiệm về bài viết: Võ Hoàng Liêm Đức Tâm (email:vhldtam@ctu.edu.vn)

\section{Thông tin chung:}

Ngày nhận bài: 22/02/2021

Ngày nhận bài sưa: 10/05/2021

Ngày duyệt đăng: 01/06/2021

\section{Title:}

The effect of juvenile density on cultured efficiency of freshwater prawn

(Macrobrachium rosenbergii) in integrated rice - prawn system in brackish water area

\section{Tù khóa:}

Giống, lúa, mật độ, tôm càng xanh, xen canh

\section{Keywords:}

Density, freshwater prawn, integration, juvenile, rice

\begin{abstract}
The effect of density on technical and financial efficiency of freshwater prawn (Macrobrachium rosenbergii) culture in integrated rice - prawn system in brackish area was conducted to find out the optimal stocking density. The experiment was completely randomized designed in 3 different densities treatments (NT1, NT2 and NT3) in correspondence to 1.5, 2 and 2.5 juveniles $/ \mathrm{m}^{2}$ and triplicate each. The initial mean weight of juveniles was $12.7 \pm 2.14 \mathrm{~g}$. Salinity in the rice field varied in the range of $0 \%$ o to $7 \%$. The results show that water quality parameters, density of planktons and benthos were in the suitable ranges for prawn growth. After 100 days of culture, the final mean weight of prawn in NT1 was $39.7 \pm$ $0.38 \mathrm{~g}$, which was significantly different $(p<0.05)$ from NT2 and NT3. The survival rate and yield were $56.4 \pm 1.9 \%$ and $336 \pm 10.5 \mathrm{~kg} / \mathrm{ha}, 52.6 \pm$ $1.7 \%$ and $362 \pm 6.4 \mathrm{~kg} / \mathrm{ha}$ and $50.6 \pm 2.0 \%$ and $395 \pm 9.1 \mathrm{~kg} / \mathrm{ha}$ in NTl, $N T 2$ and NT3, respectively. The cost benefit ratio of prawn culture was highest in NT1. In short, the density of 1.5 juvenile/m ${ }^{2}$ gave the highest economic return of the three density treatments.
\end{abstract}

\section{TÓM TẮT}

Anh hương của mật độ thả giống lên hiệu quả nuôi tôm càng xanh xen canh với lúa vùng nước lợ được thưc hiện nhằm tìm ra mật độ nuôi thích hơp. Thi nghiệm được bố trí hoàn toàn ngẫu nhiên với 3 nghiệm thức (NT1, NT2 và NT3) mật độ 1,5; 2 và 2,5 con $/ \mathrm{m}^{2}$; mỗi nghiệm thức được

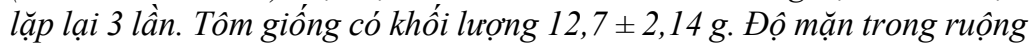
dao động tù 0 - 7\%o. Một số yếu tố môi truờng nước và mật độ thủy sinh vật trong ruộng thích hơp cho tôm càng xanh sinh truởng. Sau 100 ngày, khối lượng tôm cao nhất ở NT1 $(39,7 \pm 0,38 \mathrm{~g})$ khác biệt có ý nghĩa thống kê $(p<0,05)$ so với NT2 và NT3. Tỷ lệ sống và năng suất tôm nuôi ở NT1 lần lươt là $56,4 \pm 1,9 \%$ và $336 \pm 10,5 \mathrm{~kg} / \mathrm{ha}$, NT2 là $52,6 \pm 1,7 \%$ và 362 $\pm 6,4 \mathrm{~kg} / \mathrm{ha}$ và NT3 là $50,6 \pm 2,0 \%$ và $395 \pm 9,1 \mathrm{~kg} / \mathrm{ha}$. Tỷ suất lơi nhuận cao nhất ở NT1. Nuôi tôm càng xanh xen canh trong ruộng mật độ giống $1,5 \mathrm{con} / \mathrm{m}^{2}$ đạt hiệu quả tốt.

\section{GIỚI THIỆU}

Mô hình nuôi tôm - lúa ở Đồng bằng sông Cửu Long phát triển mạnh trong những năm gần đây. Sản lượng tôm nuôi từ hệ thống tôm - lúa năm 2014 ước tính đạt 65.000 tấn, chiếm $15 \%$ tổng sản lượng tôm nuôi nước lợ vùng ĐBSCL. Các tỉnh nuôi tôm - lúa 
có diện tích lớn là: Kiên Giang, Cà Mau, Bạc Liêu, Sóc Trăng. Năm 2018, tỉnh Cà Mau có tổng diện tích nuôi tôm càng xanh là 18.315 ha, sản lượng đạt 2.700 tấn chủ yếu tập trung ở huyện Thới Bình (Chi cục Thủy sản tỉnh Cà Mau, 2018). Nuôi tôm - lúa là hình thức nuôi trồng được đánh giá là mô hình canh tác hiệu quả, đầu tư thấp (Tổng cục Thủy sản, 2015). Tôm nuôi trong ruộng sử dụng chủ yếu thức ăn tự nhiên, chi phí thức ăn thấp, ít bệnh, tôm nuôi thương phẩm được người tiêu dùng ưa chuộng do ít dùng hóa chất, không dùng thuốc kháng sinh, môi trường sinh thái được bảo vệ do lúa sử dụng các sản phẩm thải từ nuôi tôm và đây là mô hình nuôi trồng phù hợp với điều kiện sinh thái ở các vùng ven biển bị ảnh hưởng của xâm nhập mặn, không có khả năng trồng lúa quanh năm (Dương Nhựt Long và ctv., 2018). Huyện Thới Bình mùa mưa nước ngọt $(0 \%)$ hoặc lợ $(4-6 \%)$ thích hợp nuôi tôm càng xanh. Ngoài mô hình sản xuất lúa - tôm sú luân canh, huyện đang phát triển nuôi tôm càng xanh gần 2.000 ha với mật độ thả nuôi từ $0,5-3 \mathrm{con} / \mathrm{m}^{2}$, năng suất tôm nuôi bình quân đạt từ $150-200 \mathrm{~kg} / \mathrm{ha} / \mathrm{vụ}$, mang lại lợi nhuận khá cao (Chi cục Thủy sản tỉnh Cà Mau, 2018). Để cải thiện tỷ lệ sống, tôm càng xanh được ương từ tôm bột (postlarvae 15 ngày) lên giống (Võ Hoàng Liêm Đức Tâm và ctv., 2020). Nghiên cứu ảnh hưởng của mật độ thả giống lên hiệu quả nuôi tôm càng xanh xen canh trong ruộng lúa ở vùng nước lợ được thực hiện nhằm xác định mật độ nuôi thích hợp mang lại hiệu quả kỹ thuật và tài chính cao

\section{PHƯƠNG PHÁP NGHIÊN CÚU}

\subsection{Chuẩn bị thí nghiệm}

Nghiên cứu được thực hiện từ tháng 7 năm 2019 đến tháng 01 năm 2020 tại xã Thới Bình, huyện Thới Bình, tỉnh Cà Mau. Ruộng lúa được thực hiện có diện tích 0,4 ha được chia thành khu ương diện tích ương $2.000 \mathrm{~m}^{2}$ và khu nuôi chia thành 9 ô theo chiều dọc của ruộng bằng cách dùng lưới ngăn (mắt lưới $1 \mathrm{~mm}$ ). Mỗi ô ruộng thí nghiệm có diện tích $200 \mathrm{~m}^{2}$. Mương bao quanh ruộng sâu từ $1-1,2 \mathrm{~m}$. Mực nước trên trảng (mặt ruộng) từ $0,5-0,6 \mathrm{~m}$, mặt mương từ $3-4 \mathrm{~m}$ và đáy mương từ $2-3 \mathrm{~m}$. Bờ ruộng bao quanh mương bao từ 1,5-2 m. Ruộng lúa được thiết kế gồm 2 cống, cống cấp và cống thoát nước, khẩu độ cống dao động từ $30-40 \mathrm{~cm}$ như nhau cho cống cấp và cống thoát. Trước khi thả giống, ruộng được dọn dẹp cây cỏ thủy sinh, tát cạn nước, diệt cá tạp bằng dây thuốc cá với liều lượng $1,5 \mathrm{~kg} / 1.000 \mathrm{~m}^{2}$, sên vét bùn đáy, gia cố bờ và rải vôi $15 \mathrm{~kg} / 100 \mathrm{~m}^{2}$, phơi ruộng 5 ngày. Sau đó cấp nước vào ruộng qua lưới lọc, mắt lưới $1 \mathrm{~mm}$ để ngăn chặn cá tạp và địch hại. Sử dụng bột cá (60\% protein) với liều lượng 2 $\mathrm{kg} / 2.000 \mathrm{~m}^{2}$ để gây màu nước, thời gian gây màu nước là 2 ngày. Tôm giống được chọn đều cỡ có khối lượng $12,7 \pm 2,14 \mathrm{~g}$, bao gồm cả tôm đực và tôm cái.

Lúa được trồng trong ruộng là giống lúa Một Bụi Đỏ. Thời gian canh tác lúa 3 tháng kể từ ngày cấy (cây mạ 30 ngày tuổi). Lúa được cấy 15 ngày trước khi thả tôm giống nuôi, thời điểm cấy lúa, độ mặn trong các ô ruộng là $2 \%$. không bón phân cho lúa, nguồn chất dinh dưỡng cho lúa từ vụ nuôi tôm sú trước và nuôi tôm càng xanh xen canh, bao gồm vật chất hữu cơ từ thức ăn thừa và sản phẩm bài tiết của tôm.

\subsection{Bố trí thí nghiệm}

Tôm càng xanh thả nuôi theo 3 nghiệm thức (NT1, NT2 và NT3) mật độ tôm giống là 1,$5 ; 2$ và $2,5 \mathrm{con} / \mathrm{m}^{2}$, mỗi nghiệm thức được lặp lại 3 lần. Thí nghiệm được bố trí hoàn toàn ngẫu nhiên.

Tôm nuôi được cho ăn thức ăn công nghiệp (thức ăn tôm sú có hàm lượng protein $35 \%$ ), kích cỡ viên $1,5-2 \mathrm{~mm}$ và thức ăn tươi sống (cá phèn, cá lù đù, cá rô phi...) được cắt khúc khi cho tôm ăn với kích cỡ từ $15-20 \mathrm{~mm}$, để thuận lợi cho việc bắt mồi của tôm. Hai tháng đầu của vụ nuôi, cho tôm ăn một ngày thức ăn công nghiệp và một ngày thức ăn tươi sống. Từ tháng nuôi thứ ba, một ngày cho tôm ăn thức ăn công nghiệp và ba ngày cho ăn thức ăn tươi sống. Cho tôm ăn 2 lần/ngày $(7-8$ giờ và $17-18$ giờ) với khẩu phần ăn dao động từ $5-10 \%$ khối lượng. Kiểm tra tình trạng sử dụng thức ăn của tôm thông qua sàng ăn để điều chỉnh lượng thức ăn. Thay nước định kỳ $15-20$ ngày/lần, thay $20-30 \%$ thể tích nước trong ruộng.

\subsection{Phương pháp thu mẫu}

Các chỉ tiêu thủy lý, hóa môi trường nước, thủy sinh vật và tăng trưởng của tôm được định kỳ thu mẫu mỗi tháng 1 lần. Thu mẫu vào buổi sáng lúc 7 -9 giờ.

Các chỉ tiêu thủy, lý hóa môi trường nước (nhiệt

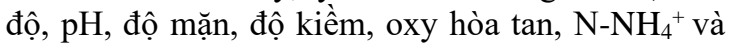
$\mathrm{N}-\mathrm{NO}_{2}{ }^{-}$) được đo trực tiếp tại các ô ruộng thí nghiệm. Nhiệt độ và $\mathrm{pH}$ được đo bằng máy Hanna, độ mặn được đo bằng khúc xạ kế. Hàm lượng $\mathrm{DO}$, $\mathrm{NH}_{4}{ }^{+}, \mathrm{NO}_{2}{ }^{-}$và độ kiềm được test nhanh bằng bộ test Sera của Đức.

Mẫu định lượng thực vật nổi dùng ca nhựa thu nhiều điểm trong ô ruộng cho vào xô nhựa $20 \mathrm{~L}$ và sử dụng chai nhựa $1 \mathrm{~L}$ để chứa nước mẫu từ xô nhựa. Mẫu định lượng động vật nổi dùng xô nhựa $20 \mathrm{~L}$ thu nhiều điểm trong ruộng và cho qua lưới phiêu sinh 
động vật có mắt lưới $59 \mu \mathrm{m}$. Mẫu được trữ trong chai nhựa $110 \mathrm{~mL}$. Mẫu động thực vật nổi được cố định bằng formol với nồng độ $4 \%$.

Mẫu thực vật nổi được đếm theo ngành bằng buồng đếm Sedgewick - Rafter. Mẫu được đếm 3 lần. Mật độ thực vật nổi được xác định theo công thức: $\mathrm{Y}=\left(\mathrm{T} * \mathrm{~V}_{\mathrm{cd}} * 1.000\right) /\left(\mathrm{N} * \mathrm{~V}_{\mathrm{m}}\right)$ (trong đó, $\mathrm{Y}$ : mật độ thực vật nổi (cá thể/L); T: tổng số thực vật nổi đếm được theo ngành; $\mathrm{V}_{\text {cơ }}$ : thể tích sau khi cô đặc $(\mathrm{mL})$; $\mathrm{N}$ : số ô đếm; $\mathrm{V}_{\mathrm{m}}$ : thể tích thu mẫu $(\mathrm{mL})$.

Định lượng động vật nổi theo nhóm gồm Protozoa, Rotifera, Cladocera, Copepoda và ấu trùng Nauplius của Copepoda. Mật độ động vật nổi được xác định theo công thức: $\mathrm{P}=\left(\mathrm{T} * \mathrm{~V}_{\mathrm{cd}} *\right.$ $1000) /\left(\mathrm{N} * \mathrm{~V}_{\mathrm{m}}\right)^{*} 10^{6}$ (trong đó: P: mật độ động vật nổi (cá thể/ $\left.\mathrm{m}^{3}\right)$; $\mathrm{T}$ : tổng số cá thể đếm được theo từng nhóm; $\mathrm{V}_{\text {cd: }}$ thể tích mẫu cô đặc $(\mathrm{mL}) ; \mathrm{N}$ : số ô đếm (180 ô); $\mathrm{V}_{\mathrm{m}}$ : thể tích mẫu nước thu $(\mathrm{mL})$.

Mẫu động vật đáy được thu bằng gàu Petersen và cho vào sàng đáy (mắt lưới $0,5 \mathrm{~mm}$ ), tiến hành sàng, cho mẫu vào túi nilong và cố định bằng formol với nồng độ $8-10 \%$. Xác định mật độ động vật đáy $\left(\mathrm{con} / \mathrm{m}^{2}\right)$ bằng cách đếm số lượng cá thể theo nhóm.

Tăng trưởng của tôm được thu bằng cách chài nhiều điểm trên ô ruộng, thu ít nhất $30 \mathrm{con} / \mathrm{o}$ ruộng, tiến hành cân khối lượng tôm để theo dõi tăng trưởng và xác định khối lượng trung bình.

Tốc độ tăng trưởng tuyệt đối về khối lượng: DWG $(\mathrm{g} /$ ngày $)=\left(\mathrm{W}_{2}-\mathrm{W}_{1}\right) /\left(\mathrm{t}_{2}-\mathrm{t}_{1}\right)$. Trong đó: $\mathrm{W}_{2}$ : là khối lượng tại thời điểm $\mathrm{t}_{2}(\mathrm{~g}) ; \mathrm{W}_{1}$ : là khối lượng tại thời điểm $\mathrm{t}_{1}(\mathrm{~g})$

Khi thu hoạch, tỷ lệ sống và năng suất tôm nuôi được xác định theo công thức:

Tỷ lệ sống $(\%)=$ (Tổng số cá thể tôm thu/Số cá thể tôm thả nuôii) x 100

Năng suất tôm nuôi $(\mathrm{kg} / \mathrm{ha})=$ Tổng khối lượng tôm thu được $(\mathrm{kg}) / \mathrm{Diện} \mathrm{tích} \mathrm{nuôi} \mathrm{(ha)}$

\subsection{Phân tích hiệu quả tài chính mô hình xen canh tôm càng xanh trong ruộng lúa}

Hiệu quả tài chính mang lại từ mô hình nuôi tôm càng xanh xen canh với lúa được tính toán. Tổng chi phí bao gồm chi phí cố định (khấu hao công trình ruộng nuôi, máy bơm nước, chài và lưới kéo tôm, thời gian khấu hao là ba năm), chi phí biến đổi (chi phí cải tạo ao nuôi, vôi bột, dây thuốc cá, tôm giống, thức ăn, chất dinh dưỡng bổ sung, nhiên liệu, công lao động). Tổng thu từ tôm (triệu đồng/ha) = Tổng sản lượng tôm thu hoạch $(\mathrm{kg} / \mathrm{ha}) \mathrm{x}$ Giá bán (đồng $/ \mathrm{kg}$ ).
Lợi nhuận (triệu đồng/ha) = Tổng thu - Tổng chi.

Tỷ suất lợi nhuận $(\%)=$ (Lợi nhuận/tổng chi phí) $\mathrm{x} 100$.

\subsection{Xử lý số liệu}

Số liệu mật độ thực vật nổi, động vật nổi, mật độ động vật đáy, các chỉ tiêu hiệu quả mô hình nuôi tôm càng xanh được xử lý thống kê ANOVA 1 nhân tố và phép thử DUNCAN ở mức ý nghĩa $\mathrm{p}<0,05$ bằng phần mềm SPSS 20.0.

\section{KẾT QUẢ VÀ THẢO LUẬN}

\subsection{Một số yếu tố thủy, lý hóa trong nước ruộng nuôi tôm càng xanh}

Các yếu tố thủy lý, hóa nước ở các nghiệm thức biến động không lớn do các ô ruộng được ngăn bằng lưới nên nước có thể trao đổi qua lại. Nhiệt độ nước trung bình trong thời gian nuôi tôm ở 3 nghiệm thức từ $30,8-31,4^{\circ} \mathrm{C}$. Theo Nguyễn Thanh Phương và Trần Ngọc Hải (2003), tôm càng xanh phát triển tốt trong khoảng nhiệt độ $25-31^{\circ} \mathrm{C}$. Trong khoảng nhiệt độ thích hợp, nhiệt độ càng cao chu kỳ lột xác của tôm nuôi càng ngắn, tôm phát triển nhanh (Nguyễn Thị Thu Thuỷ, 2000). Do vậy, với những số liệu ghi nhận về nhiệt độ ở các nghiệm thức khá thuận lợi cho sự sinh trưởng và phát triển của tôm càng xanh. $\mathrm{pH}$ trung bình ở các nghiệm thức qua các tháng nuôi dao động từ $7,8-8,1$. Trong đó cao nhất là NT3, kế đến là NT2 và thấp nhất là ở NT1, do ở NT3 mật độ thả giống cao nhất trong quá trình nuôi tích lũy nhiều dinh dưỡng làm cho phiêu sinh thực vật phát triển nên có giá trị $\mathrm{pH}$ cao. Theo Đỗ Thị Thanh Hương và ctv. (2014), $\mathrm{pH}$ thích hợp trong nuôi tôm càng xanh là từ $7,0-9,0$ và tối ưu nhất là $\mathrm{pH}=8,0$. Giá trị $\mathrm{pH}$ trung bình ở các nghiệm thức đều nằm trong khoảng thích hợp cho tăng trưởng của tôm. Độ kiềm trung bình ở các nghiệm thức từ 162 - $168 \mathrm{mg} \mathrm{CaCO}_{3} / \mathrm{L}$ (dao động từ 160 - $172 \mathrm{mg}$ $\left.\mathrm{CaCO}_{3} / \mathrm{L}\right)$. Theo Nguyễn Thanh Phương và Trần Ngọc Hải (2003), độ kiềm thích hợp cho tôm càng xanh từ $50-150 \mathrm{mg} \mathrm{CaCO}_{3} / \mathrm{L}$. Kết quả khảo sát qua các đợt thu mẫu độ kiềm khá cao nhưng qua số liệu thu mẫu tăng trưởng (Bảng 3 ) cho thấy tôm càng xanh vẫn tăng trưởng tốt trong suốt quá trình nuôi. Hàm lượng oxy hòa tan trung bình ở các nghiệm thức từ 4,0-5,0 mg/L. Hàm lượng oxy hòa tan cao nhất là ở NT1 và thấp nhất là ở NT3, nguyên nhân do quá trình oxy hóa vật chất hữu cơ từ chất thải của tôm nuôi, đặc biệt ở những nghiệm thức có mật độ càng cao, hàm lượng oxy hòa tan trong nước giảm. Tuy nhiên, hàm lượng oxy hòa tan trong các ô nuôi vẫn ở mức thích hợp, thuận lợi cho quá trình hô hấp, 
trao đổi chất và lột xác của tôm nuôi. Theo New (2002), hàm lượng oxy hòa tan dao động từ 4,5 - 6,0 $\mathrm{mg} / \mathrm{L}$ là tối ưu, từ $3,5-4,5 \mathrm{mg} / \mathrm{L}$ tôm sinh trưởng tốt. Hàm lượng ${\mathrm{N}-\mathrm{NH}_{4}}_{4}$ trung bình từ $0,50-0,56$ $\mathrm{mg} / \mathrm{L}$, hàm lượng $\mathrm{N}-\mathrm{NH}_{4}{ }^{+}$có xu hướng gia tăng về cuối vụ và theo mật độ thả giống. Nguyên nhân của hiện tượng này có thể là do sự gia tăng về hàm lượng dinh dưỡng từ chất thải của tôm trong quá trình nuôi và sự phân hủy của rơm, rạ sau khi thu hoạch lúa làm gia tăng hàm lượng ammonium trong các ruộng nuôi. Theo Trần Thanh Hải (2007), hàm lượng N$\mathrm{NH}_{4}{ }^{+}$thích hợp cho ao nuôi tôm càng xanh thương phẩm là thấp hơn $1,5 \mathrm{mg} / \mathrm{L}$. Do đó, hàm lượng $\mathrm{NH}_{4}{ }^{+}$ ở các nghiệm thức thích hợp cho sinh trưởng của tôm càng xanh. Hàm lượng $\mathrm{N}^{-\mathrm{NO}_{2}}{ }^{-}$trung bình từ
$0,09-0,10 \mathrm{mg} / \mathrm{L}$. Hàm lượng $\mathrm{N}^{-\mathrm{NO}_{2}}{ }^{-}$không có nhiều biến động ở các nghiệm thức và trong giới hạn cho phép không gây ảnh hưởng đến tăng trưởng của tôm. Theo New (2002), hàm lượng $\mathrm{N}^{-\mathrm{NO}_{2}}{ }^{-}$trong thủy vực nuôi duy trì ở mức $<0,1 \mathrm{mg} / \mathrm{L}$. Đỗ Thị Thanh Hương và Cao Châu Minh Thư (2012) cho rằng khi nồng độ nitrite tăng ảnh hưởng đến tốc độ tăng trưởng và lột xác của tôm càng xanh. Nhìn chung, hàm lượng oxy hòa tan giảm nhưng $\mathrm{pH}$, $\mathrm{NH}_{4}{ }^{+}$và $\mathrm{NO}_{2}{ }^{-}$gia tăng về cuối vụ nuôi do sự tích lũy các vật chất hữu cơ trong quá trình nuôi tôm cũng như sự phân hủy của rơm, rạ sau khi thu hoạch lúa. Tuy nhiên, các yếu tố này chưa ảnh hưởng bất lợi đến sinh trưởng của tôm càng xanh.

Bảng 1. Các yếu tố thủy lý, hóa trong nước ruộng nuôi tôm càng xanh

\begin{tabular}{lrrr}
\hline Chỉ tiêu & NT1 & NT2 & NT3 \\
\hline Nhiệt độ $\left({ }^{\circ} \mathrm{C}\right)$ & $30,8 \pm 0,8$ & $31,2 \pm 0,4$ & $31,4 \pm 0,5$ \\
pH & $7,8 \pm 0,8$ & $7,9 \pm 0,4$ & $8,1 \pm 0,3$ \\
Độ kiềm $\left(\mathrm{mg} \mathrm{CaCO}_{3} / \mathrm{L}\right)$ & $162,0 \pm 1,4$ & $163,4 \pm 1,5$ & $168,6 \pm 4,4$ \\
Oxy hòa tan $(\mathrm{mg} / \mathrm{L})$ & $5,0 \pm 0,1$ & $4,5 \pm 0,3$ & $4,0 \pm 0,4$ \\
$\mathrm{~N}^{-N_{4}}{ }^{+}(\mathrm{mg} / \mathrm{L})$ & $0,50 \pm 0,03$ & $0,50 \pm 0,01$ & $0,56 \pm 0,02$ \\
$\mathrm{~N}_{-} \mathrm{NO}_{2}{ }^{-}(\mathrm{mg} / \mathrm{L})$ & $0,09 \pm 0,01$ & $0,09 \pm 0,02$ & $0,10 \pm 0,03$ \\
\hline
\end{tabular}

Độ mặn ban đầu lúc thả giống là $2 \%$ và giảm còn $0 \%$ trong tháng nuôi thứ nhất đến tháng nuôi thứ 2. Tuy nhiên, vào tháng nuôi thứ ba (tháng 12/2019), độ mặn bắt đầu tăng ở trong ruộng nuôi tôm và kênh cấp nước (Hình 1$)$. Tôm càng xanh sống được trong môi trường nước có độ mặn từ 0 $25 \%$ nhưng tôm sinh trưởng và phát triển tốt ở độ mặn từ $0-16 \%$, thích hợp nhất là từ $0-12 \%$ (Phạm Văn Tình, 2004; Đỗ Thị Thanh Hương \& Nguyễn Văn Tư, 2010). Theo Chand et al. (2015), độ mặn

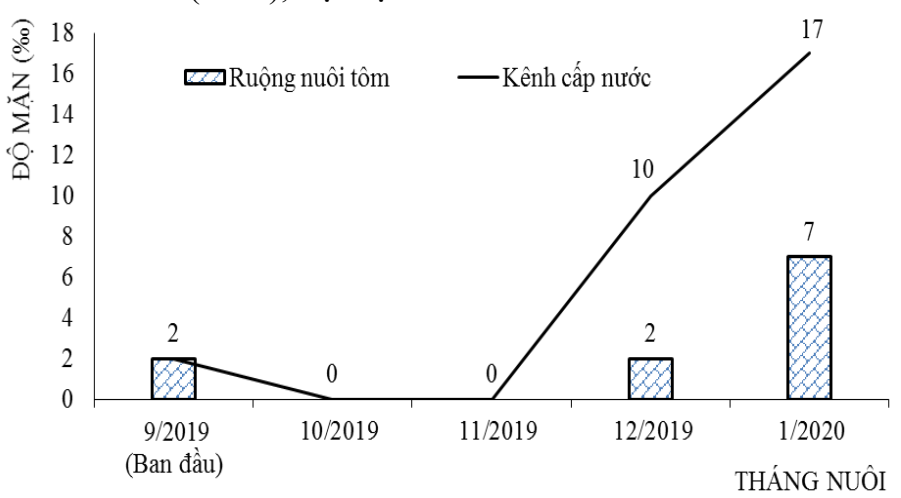

\section{Hình 1. Biến động độ mặn trong ruộng nuôi tôm và kênh cấp nước}

\subsection{Thủy sinh vật trong ruộng nuôi tôm càng xanh}

\subsubsection{Thực vật nổi (phytoplankton)}

Mật độ thực vật nổi ở NT1 dao động từ 31.111 75.926 cá thể/L, NT2 là $35.556-75.185$ cá thể/L và gây chết $50 \%$ tôm càng xanh giống sau 96 giờ là $24,6 \%$ và tôm càng xanh tăng trưởng tốt trong khoảng độ mặn 0 - 15\%o nhưng tốt nhất ở độ mặn 10\%o. Độ mặn trong vụ nuôi tôm càng xanh ở vùng nước lợ tỉnh Trà Vinh dao động từ 2 - 10\%o (Hai et al., 2017). Vì vậy, khi độ mặn kênh cấp nước ở địa điểm thí nghiệm tăng cao đến 17\%o (tháng 01/2020), ruộng nuôi không thay nước và tôm tăng trưởng chậm nên tiến hành thu hoạch tôm.

NT3 là $32.222-78.519$ cá thể/L (Hình 2). Mật độ thực vật nổi khác biệt không có ý nghĩa thống kê (p>0,05) ở 3 nghiệm thức, do các ô ruộng được ngăn bằng lưới nên nước và thực vật nổi có thể trao đổi qua lại giữa các nghiệm thức. Mật độ thực vật nổi ở 
3 nghiệm thức tăng vào cuối vụ nuôi, do việc tích lũy vật chất hữu cơ từ thức ăn và sản phẩm bài tiết của tôm ngày càng tăng. Mật độ tảo khuê (Bacillariophyta) chiếm ưu thế tạo điều kiện cho tôm phát triển, đây là những giống loài phiêu sinh thực vật thường phân bố trong các loại hình nước lợ, vùng Đồng bằng Sông Cửu Long (Dương Nhựt Long và ctv., 2015). Theo Trần Thị Thanh Hiền và Nguyễn Anh Tuấn (2009), thực vật nổi là mắt xích đầu tiên trong chuỗi thức ăn tự nhiên của thủy vực nước.

\subsection{2. Động vật nổi (Zooplankton)}

Mật độ động vật nổi ở NT1 dao động từ 38.519 - 91.852 cá thể $/ \mathrm{m}^{3}, \mathrm{NT} 2$ từ $35.926-80.370$ cá thể/ $/ \mathrm{m}^{3}$, NT3 từ $27.778-73.704$ cá thể/ $/ \mathrm{m}^{3}$. Mật độ động vật nổi khác biệt có ý nghĩa thống kê $(\mathrm{p}<0,05)$ ở cả ba nghiệm thức, trong đó mật độ cao nhất là ở NT1, kế đến NT2 và NT3. Mật độ của nhóm
Protozoa, Nauplius và Rotifera (Hình 3 ) chiếm ưu thế, đặc biệt là Rotifera với mật độ cao, ngành Copepoda và Cladocera có mật độ thấp hơn. Mật độ động vật nổi tăng dần về cuối vụ, do quá trình tích lũy vật chất hữu cơ trong quá trình nuôi. Bên cạnh đó khi tôm càng xanh trưởng thành, thì động vật phiêu sinh không còn là nguồn thức ăn chính cho tôm. Theo Nguyễn Thanh Phương và Trần Ngọc Hải (2003), tính ăn của tôm càng xanh thay đổi theo giai đoạn phát triển, sinh lý và điều kiện môi trường. Khi còn nhỏ tôm càng xanh ăn sinh vật phù du (động vật, thực vật phù du), giun nhỏ hay ấu trùng của động vật thủy sinh. Tôm càng xanh lớn ăn tạp thiên về động vật (giun, ốc,...). Theo Đặng Ngọc Thanh và ctv. (2002), động vật nổi là thức ăn cần thiết cho ấu trùng các loài cá, tôm, cua, nhuyễn thể và nó đóng vai trò quan trọng như ăn lọc hiệu quả trên thực vật nổi, và cũng là nguồn thức ăn cho động vật không xương sống khác.
NGHIẸM THÚC 1

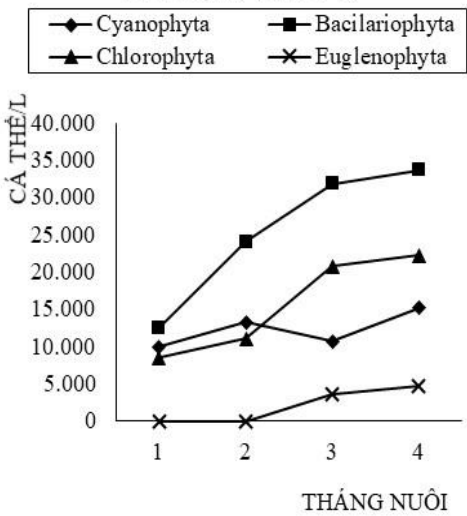

NGHIẸM THỨC 2

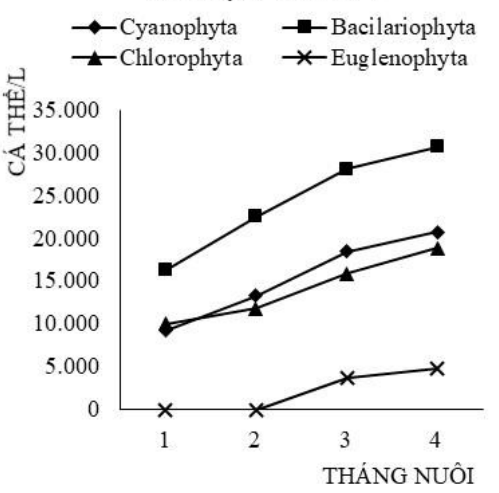

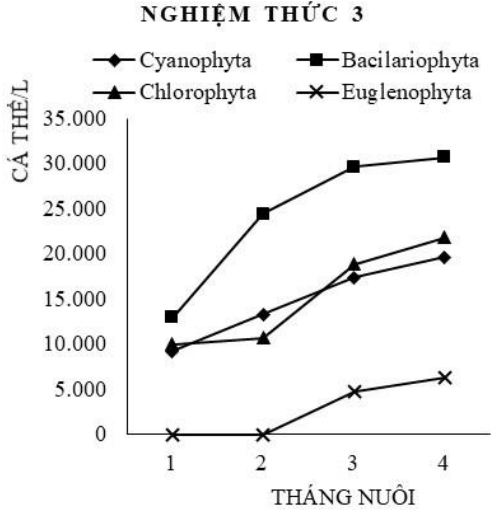

Hình 2. Mật độ thực vật nổi ở các nghiệm thức mật độ tôm càng xanh nuôi xen canh trong ruộng
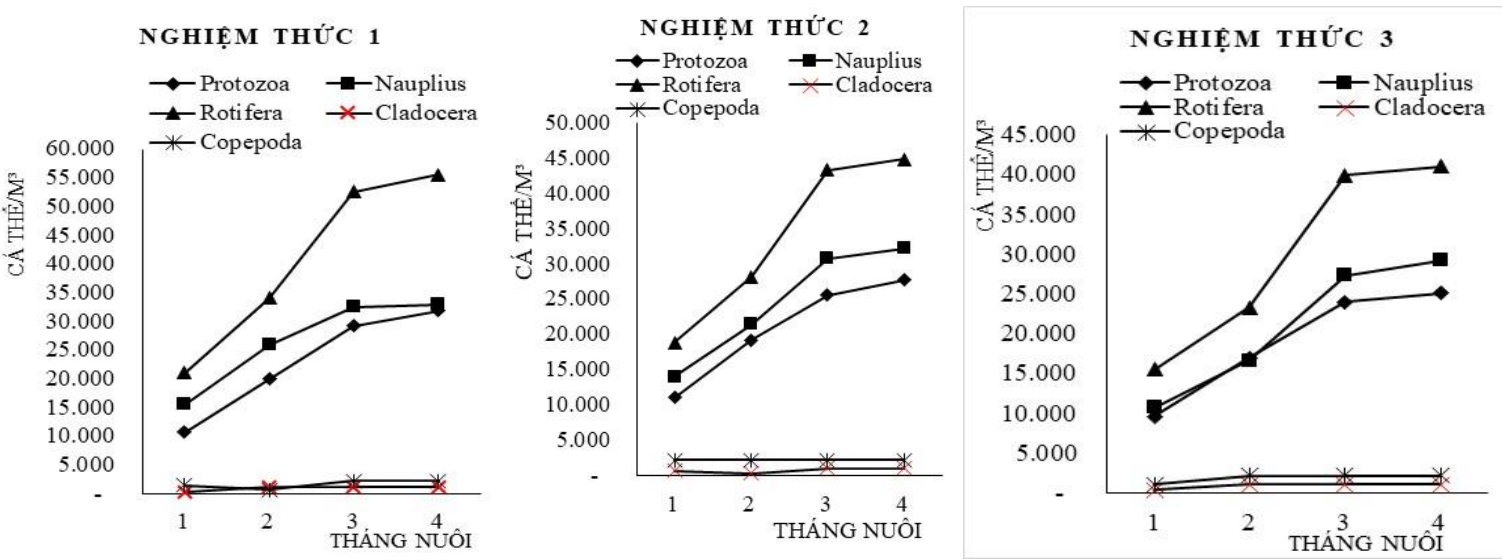

Hình 3. Mật độ động vật nổi ở các nghiệm thức mật độ tôm càng xanh nuôi xen canh trong ruộng 


\subsection{3. Động vật đáy (Zoobenthos)}

Động vật đáy ở ba nghiệm thức cho thấy nhóm giun ít tơ (Oligochaeta) 2 loài, chân bụng (Gastropoda) 10 - 12 loài, nhóm giun nhiều tơ (Polychaeta) 2 loài. Giống loài thường gặp và chiếm ưu thế ở hầu hết các hệ thống nuôi qua các đợt khảo sát là Tylomelania sp. (Gastropoda). Mật độ động vật đáy biến động ít qua các tháng (Hình 4). Mật độ Oligochaeta và Polychaeta ở NT1 khác biệt không có ý nghĩa thống kê $(\mathrm{p}>0,05)$ so với NT2 nhưng khác biệt có ý nghĩa thống kê $(\mathrm{p}<0,05)$ so với NT3. Mật độ Gastropoda và mật độ tổng các nhóm ngành động vật đáy ở NT1 cao hơn có ý nghĩa thống kê $(\mathrm{p}<0,05)$ so với NT2 và NT3 (Bảng 2). NT1 mật độ tôm thấp nên tôm càng xanh sử dụng thức ăn từ động vật đáy cũng ít hơn nên mật độ động vật đáy ở NT1 cao hơn so với hai nghiệm thức còn lại. Theo Nguyễn Thanh Phương và Trần Ngọc Hải (2003), tính ăn của tôm càng xanh thay đồi theo giai đoạn phát triển, khi tôm càng xanh trưởng thành có tính ăn tạp thiên về động vật.
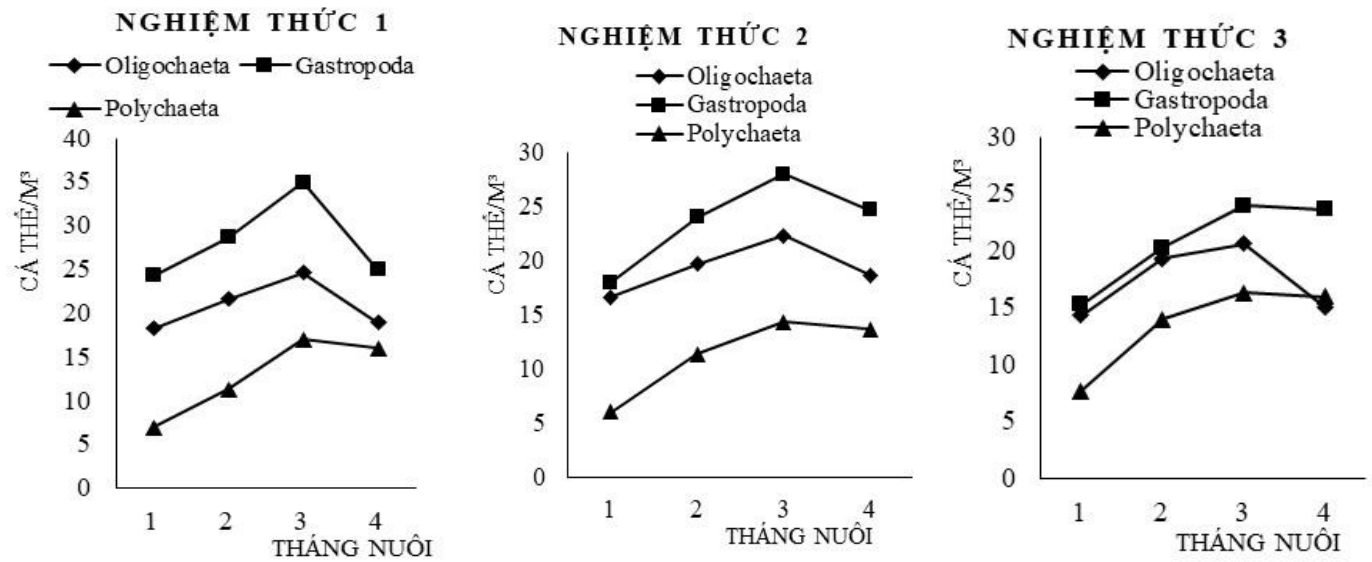

Hình 4. Mật độ động vật đáy ở các nghiệm thức mật độ tôm nuôi

Mật độ động vật đáy trung bình ở các nghiệm thức từ $51,6-62,0 \mathrm{con} / \mathrm{m}^{2}$. Kết quả này thấp hơn so với nghiên cứu của Dương Nhựt Long và ctv. (2015) thực hiện trong ao nuôi tôm càng xanh thâm canh ở tỉnh Hậu Giang, kết quả khảo sát nhóm động vật đáy chiếm ưu thế là giun ít tơ (Oligochaeta) với các loài thường gặp là Tubifex sp, Branchyura sowerbyi, Limnodrius hoffmeisteri, Claparede. Số lượng động vật đáy dao động từ $48-124 \mathrm{con} / \mathrm{m}^{2}$ nhưng số loài động vật đáy thấp hơn khoảng 2 - 3 loài. Nguyên nhân có thể là do sự khác biệt về điều kiện sinh thái ở hai vùng khác nhau, nghiên cứu của Dương Nhựt Long và ctv. (2015) thực hiện ở vùng sinh thái nước ngọt, thí nghiệm này được thực hiện ở vùng sinh thái nước lợ, độ mặn có nhiều thay đổi (Hình 1), phần nào ảnh hưởng đến biến động số lượng động vật đáy (Hình 4). Nhìn chung, thành phần loài và số lượng động vật đáy trong các ruộng nuôi khá phong phú và đa dạng, là nguồn thức ăn tự nhiên cho tôm càng xanh.

\section{Bảng 2. Số lượng động vật đáy trong ruộng nuôi}

\begin{tabular}{crrrr}
\hline $\begin{array}{c}\text { Nghiệm } \\
\text { thức }\end{array}$ & $\begin{array}{r}\text { Oligochaeta } \\
\left(\mathbf{c o n} / \mathbf{m}^{2}\right)\end{array}$ & $\begin{array}{r}\text { Gastropoda } \\
\left(\mathbf{c o n} / \mathbf{m}^{2}\right)\end{array}$ & Polychaeta $\left(\mathbf{c o n} / \mathbf{m}^{2}\right)$ & Tổng $\left(\mathbf{c o n} / \mathbf{m}^{2}\right)$ \\
\hline NT1 & $20,9 \pm 2,8^{\mathrm{b}}$ & $28,2 \pm 4,8^{\mathrm{c}}$ & $12,8 \pm 4,6^{\mathrm{ab}}$ & $62,0 \pm 11,1^{\mathrm{b}}$ \\
NT2 & $19,3 \pm 2,3^{\mathrm{ab}}$ & $23,6 \pm 4,1^{\mathrm{b}}$ & $11,3 \pm 3,7^{\mathrm{a}}$ & $54,3 \pm 10^{\mathrm{a}}$ \\
NT3 & $17,3 \pm 3,1^{\mathrm{a}}$ & $20,8 \pm 4^{\mathrm{a}}$ & $13,5 \pm 4^{\mathrm{b}}$ & $51,6 \pm 10^{\mathrm{a}}$ \\
\hline
\end{tabular}

Các số liệu trong cùng một cột theo sau bởi các chũ cái giống nhau thì khác biệt không có ý nghĩa thống kê (p>0,05).

\subsection{Tăng trưởng, tỷ lệ sống và năng suất của tôm nuôi}

\subsubsection{Tăng trưởng của tôm càng xanh nuôi xen canh trong ruộng lúa}

Sau 100 ngày nuôi, do nước ở kênh cấp có độ mặn cao (17\%), không thay nước được và tôm tăng trưởng chậm nên tiến hành thu hoạch toàn bộ. Khối lượng tôm càng xanh trong 30 ngày đầu không có sự khác biệt giữa các nghiệm thức $(\mathrm{p}>0,05)$ (Bảng 3$)$. Ở ngày 60 , khối lượng trung bình của tôm ở NT1 và NT2 khác biệt không có ý nghĩa thống kê $(p>0,05)$ nhưng khác biệt có ý nghĩa thống kê so với NT3 $(p<0,05)$. Từ ngày 90 đến thu hoạch, khối lượng tôm 
càng xanh lớn nhất ở nghiệm thức 1 khác biệt có ý nghĩa thống kê $(p<0,05)$ so với hai nghiệm thức còn lại.

Tốc độ tăng trưởng tuyệt đối của tôm càng xanh nuôi qua các tháng có sự biến động giữa các nghiệm thức. Tốc độ tăng trưởng tuyệt đối trung bình của tôm càng xanh sau 100 ngày nuôi ở nghiệm thức 1 nhanh nhất và khác biệt có ý nghĩa thống kê $(\mathrm{p}<0,05)$ so với nghiệm thức 2 và nghiệm thức 3 . Tôm càng xanh nuôi ở mật độ cao tăng trưởng chậm hơn mật độ thấp do mật độ thấp giảm được sự cạnh tranh về không gian sống (Nguyễn Văn Hảo và ctv., 2002). Khối lượng tôm càng xanh thu hoạch giảm khi tăng mật độ nuôi. Kết quả này hoàn toàn phù hợp với kết quả nghiên cứu của Nguyễn Văn Hảo và ctv. (2002) khi cho rằng trong hệ thống nuôi tôm càng xanh, với tính cạnh tranh về điều kiện sinh thái và dinh dưỡng giữa các cá thể cùng loài, tốc độ tăng trưởng của tôm nuôi giảm khi mật độ thả tăng cao. Hồ Thanh Thái (2011) cho rằng nuôi tôm càng xanh xen canh trong ruộng lúa ở mật độ $1 \mathrm{con} / \mathrm{m}^{2}$ tăng trưởng nhanh hơn so với mật độ 2 và $3 \mathrm{con} / \mathrm{m}^{2}$. Theo Lam My Lan (2006), ở mô hình nuôi tôm càng xanh xen canh trong ruộng lúa, khối lượng tôm thu hoạch ở mật độ $1 \mathrm{con} / \mathrm{m}^{2}$ lớn hơn mật độ 2 và $3 \mathrm{con} / \mathrm{m}^{2}$. Theo kết quả nghiên cứu của Phạm Minh Tứ (2015), tôm nuôi trong ruộng lúa ở tỉnh Bạc Liêu mật độ 3 con $/ \mathrm{m}^{2}$, sau 6 tháng nuôi khối lượng bình quân là $35,2 \pm 4,5 \mathrm{~g} / \mathrm{con}$. Tuy nhiên, kết quả nghiên cứu này thấp hơn so với kết quả của Trần Tấn Huy và ctv. (2004), tôm nuôi trong ruộng lúa vào mùa mưa lũ ở vùng nước ngọt tại huyện Thoại Sơn, tỉnh An Giang đạt khối lượng trung bình 47,9-67,1 g/con do thời gian nuôi ở vùng nước ngọt dài hơn.

Bảng 3. Khối lượng (W), tốc độ tăng trưởng tuyệt đối (DWG), tỷ lệ sống và năng suất của tôm càng xanh nuôi xen canh trong ruộng lúa

\begin{tabular}{lrrr}
\hline Chỉ tiêu & NT1 & NT2 & NT3 \\
\hline $\mathrm{W}_{0}(\mathrm{~g})$ & $12,7 \pm 2,14^{\mathrm{a}}$ & $12,7 \pm 2,14^{\mathrm{a}}$ & $12,7 \pm 2,14^{\mathrm{a}}$ \\
$\mathrm{W}_{30 \text { ngày }}(\mathrm{g})$ & $22,2 \pm 1,05^{\mathrm{a}}$ & $23,3 \pm 0,74^{\mathrm{a}}$ & $21,7 \pm 0,73^{\mathrm{a}}$ \\
$\mathrm{W}_{60 \text { ngày }}(\mathrm{g})$ & $30,0 \pm 0,77^{\mathrm{b}}$ & $28,2 \pm 1,22^{\mathrm{b}}$ & $25,2 \pm 0,97^{\mathrm{a}}$ \\
$\mathrm{W}_{90 \text { ngày }}(\mathrm{g})$ & $36,2 \pm 1,04^{\mathrm{c}}$ & $32,4 \pm 1,02^{\mathrm{b}}$ & $29,6 \pm 1,49^{\mathrm{a}}$ \\
$\mathrm{W}_{100}$ ngày & $\mathrm{g})$ & $34,5 \pm 0,78^{\mathrm{b}}$ & $31,3 \pm 1,21^{\mathrm{a}}$ \\
$\mathrm{DWG}_{1-30 \text { ngày }}$ (g/ngày) & $39,7 \pm 0,38^{\mathrm{c}}$ & $0,35 \pm 0,03^{\mathrm{a}}$ & $0,30 \pm 0,02^{\mathrm{a}}$ \\
$\mathrm{DWG}_{31-60 \text { này }}$ (g/ngày) & $0,32 \pm 0,04^{\mathrm{a}}$ & $0,16 \pm 0,06^{\mathrm{a}}$ & $0,12 \pm 0,01^{\mathrm{a}}$ \\
$\mathrm{DWG}_{\text {61-90 ngày }}$ (g/ngày) & $0,26 \pm 0,02^{\mathrm{b}}$ & $0,14 \pm 0,08^{\mathrm{a}}$ & $0,14 \pm 0,08^{\mathrm{a}}$ \\
DWG 91-100 ngày $(\mathrm{g} /$ ngày) & $0,21 \pm 0,06^{\mathrm{a}}$ & $0,21 \pm 0,04^{\mathrm{ab}}$ & $0,18 \pm 0,09^{\mathrm{a}}$ \\
DWG & $0,36 \pm 0,10^{\mathrm{b}}$ & $0,22 \pm 0,008^{\mathrm{b}}$ & $0,19 \pm 0,012^{\mathrm{a}}$ \\
Tỷ lệ sống (\%) & $0,27 \pm 0,004^{\mathrm{c}}$ & $52,6 \pm 1,7^{\mathrm{a}}$ & $50,6 \pm 2,0^{\mathrm{a}}$ \\
Năng suất (kg/ha) & $56,4 \pm 1,9^{\mathrm{b}}$ & $362 \pm 6,4^{\mathrm{b}}$ & $395 \pm 9,1^{\mathrm{c}}$ \\
\hline
\end{tabular}

Số liệu trong cùng một hàng theo sau bởi các chũ cái giống nhau thì khác biệt không có ý nghĩa thống kê (p>0,05).

\subsubsection{Tỷ lệ sống và năng suất của tôm nuôi}

Kết quả Bảng 3 cho thấy tỷ lệ sống của tôm nuôi cao nhất ở NT1 khác biệt có ý nghĩa thống kê so với NT2 và NT3 $(p<0,05)$ do mật độ nuôi thấp tôm ít cạnh tranh về không gian sống cũng như ăn thịt nhau. Năng suất tôm nuôi của mô hình nuôi tôm càng xanh xen canh trong ruộng lúa ở NT1 bình quân đạt $336 \pm 10,5 \mathrm{~kg} / \mathrm{ha}$ thấp hơn có ý nghĩa thống kê $(\mathrm{p}<0,05)$ so với NT2 là $362 \pm 6,4 \mathrm{~kg} /$ ha và NT3 là $395 \pm 9,1 \mathrm{~kg} / \mathrm{ha}$, do NT2 và NT3 có mật độ cao hơn.

Kết quả của nghiên cứu này phù hợp với nhận định của Hồ Thanh Thái (2011) cho rằng năng suất tôm nuôi tăng theo mật độ thả nuôi, tỷ lệ sống của tôm lại có xu hướng giảm khi mật độ nuôi tăng. Kết quả nghiên cứu này tương tự kết quả nghiên cứu của Lam My Lan (2006) khi nuôi tôm càng xanh xen canh trong ruộng lúa ở vùng nước ngọt thả tôm giống, năng suất của tôm đạt $251 \pm 16 \mathrm{~kg} / \mathrm{ha}$ ở mật độ $1 \mathrm{con} / \mathrm{m}^{2} ; 369 \pm 50 \mathrm{~kg} / \mathrm{ha}$ ở mật độ $2 \mathrm{con} / \mathrm{m}^{2}$ và $430 \pm 54 \mathrm{~kg} / \mathrm{ha}$ ở mật độ $3 \mathrm{con} / \mathrm{m}^{2}$. Kết quả thực nghiệm này cao so với nghiên cứu của Phạm Minh Truyền (2003), nuôi tôm càng xanh kết hợp với trồng lúa tại tỉnh Trà Vinh với mật độ $2-3 \mathrm{con} / \mathrm{m}^{2}$, năng suất tôm đạt được từ $150-163 \mathrm{~kg} / \mathrm{ha}$, với tỷ lệ sống từ $8,8-28,7 \%$ và kết quả nghiên cứu của Dương Nhựt Long và ctv. (2018) nuôi tôm càng xanh kết hợp với lúa ở huyện Thới Bình, tỉnh Cà Mau với mật độ $3 \mathrm{con} / \mathrm{m}^{2}$, tỷ lệ sống của tôm nuôi trung bình là $33,0 \pm 12,3 \%$, năng suất trung bình 335 $\pm 153 \mathrm{~kg} / \mathrm{ha}$. Sự khác biệt này là do tôm được ương 2 tháng và tôm đưa ra ruộng được tuyển chọn đồng đều về kích cỡ, cung cấp đầy đủ thức ăn khi nuôi nên có tỷ lệ sống và năng suất tốt hơn so với các nghiên cứu khác trước đây. 


\subsection{Cơ cấu chi phí các nghiệm thức mật độ nuôi tôm càng xanh}

Chi phí thức ăn, con giống và công lao động nuôi tôm càng xanh chiếm tỷ lệ cao hơn các khoản chi khác (Hình 5). Tổng chi phí nuôi tôm càng xanh ở ba nghiệm thức đều khác biệt có ý nghĩa thống kê $(\mathrm{p}<0,05)$ (Bảng 4). Mật độ thả nuôi càng cao chi phí càng tăng dao động từ 22,392 - 30,260 triệu đồng/ha và mật độ tôm nuôi $1,5 \mathrm{con} / \mathrm{m}^{2}$ có chi phí thấp nhất nhất.

\section{NGHIEM THỨC 1}

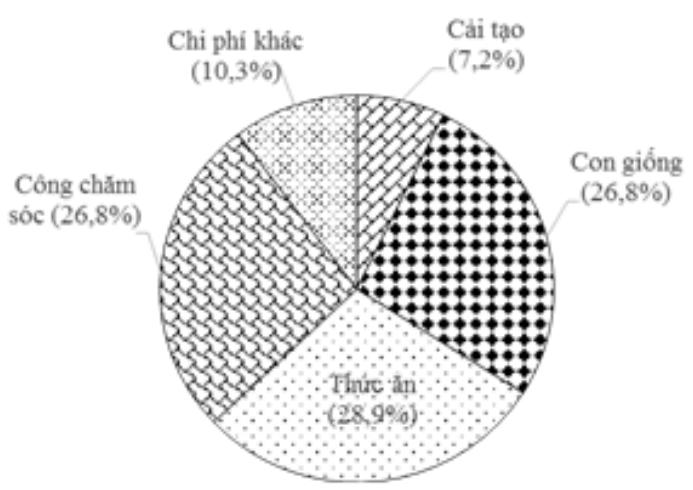

\section{NGHIĘM THỨC 2}

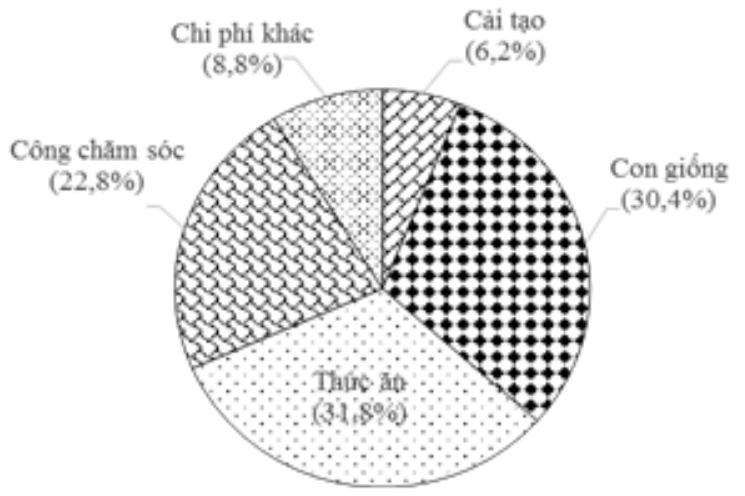

NGHIEM THƯ'C 3

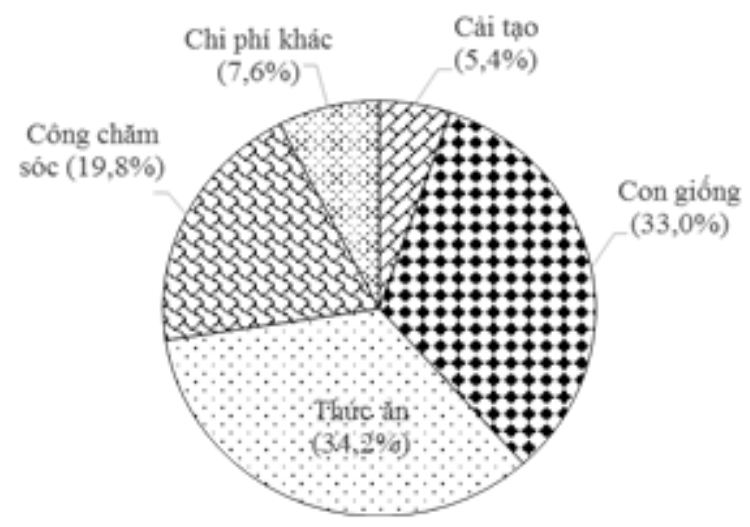

Hình 5. Tỷ lệ (\%) các chi phí của mô hình nuôi ở ba nghiệm thức mật độ tôm giống

\subsection{Hiệu quả tài chính mô hình nuôi tôm càng xanh xen canh trong ruộng lúa}

Thu nhập từ nuôi tôm ở ba nghiệm thức đều khác biệt có ý nghĩa thống kê $(\mathrm{p}<0,05)$ và ở nghiệm thức mật độ cao cho thu nhập cao do năng suất tôm cao. Lợi nhuận từ nuôi tôm càng xanh khác biệt không có ý nghĩa thống kê $(p>0,05)$ giữa các nghiệm thức mật độ. Tuy nhiên, tỷ suất lợi nhuận từ tôm $(67 \pm$ $4,4 \%$ ) đạt cao nhất ở NT1 (mật độ $1,5 \mathrm{con} / \mathrm{m}^{2}$ ) $(\mathrm{p}<0,05)$.
Kết quả tỷ lệ chi phí thức ăn thấp hơn nhưng chi phí con giống cao hơn so với kết quả nghiên cứu của Lam My Lan (2006). Tỷ suất lợi nhuận từ nuôi tôm từ $44-67 \%$ thấp hơn kêt quả của Dương Nhựt Long và ctv. (2018) vì do trong nghiên cứu này thời gian nuôi tôm ngắn hơn nên kích cỡ tôm thu hoạch và năng suất tôm thấp hơn làm cho lợi nhuận và tỷ suất lợi nhuận thấp. 
Bảng 4. Hiệu quả tài chính của tôm càng xanh nuôi trong mô hình xen canh với lúa

(Đơn vị tính: ngàn đồng/ha)

\begin{tabular}{lrrr}
\hline Nội dung & NT1 & NT2 & NT3 \\
\hline Chi phí nuôi tôm & $22.392 \pm 136^{\mathrm{a}}$ & $26.295 \pm 860^{\mathrm{b}}$ & $30.260 \pm 930^{\mathrm{c}}$ \\
Vôi & 700 & 700 & 700 \\
Thuốc cá & 600 & 600 & 600 \\
Xăng, dầu & 320 & 320 & 320 \\
Tôm giống & 6.000 & 8.000 & 10.000 \\
Thức ăn công nghiệp & 2.859 & 4.288 & 5.067 \\
Thức ăn tuoơi sống & 3.613 & 4.087 & 5.273 \\
Công chăm sóc & 6.000 & 6.000 & 6.000 \\
Thuốc, hóa chất & 300 & 300 & 300 \\
Chi phí khấu hao & 2.000 & 2.000 & 2.000 \\
\hline Tổng thu & $36.960 \pm 1.159^{\mathrm{a}}$ & $39.856 \pm 860^{\mathrm{b}}$ & $43.486 \pm 930^{\mathrm{c}}$ \\
Lợi nhuận & $14.568 \pm 1.063^{\mathrm{a}}$ & $13.562 \pm 1.531^{\mathrm{a}}$ & $13.227 \pm 1.807^{\mathrm{a}}$ \\
Tỷ suất lợi nhuận $(\%)$ & $67 \pm 4,4^{\mathrm{b}}$ & $52 \pm 7,5^{\mathrm{a}}$ & $44 \pm 7,4^{\mathrm{a}}$ \\
\hline
\end{tabular}

Các số liệu trong cùng một hàng theo sau bởi các chũ cái giống nhau thì khác biệt không có ý nghĩa thống kê (p>0,05; Giá bán tôm là 110.000 đồng/kg.

\section{KẾT LUẬN VÀ ĐỀ XUẤT}

Nuôi tôm càng xanh xen canh với lúa Một Bụi Đỏ thả tôm giống mật độ $1,5 \mathrm{con} / \mathrm{m}^{2}$ đạt khối lượng tôm lúc thu hoạch, tỷ lệ sống và tỷ suất lợi nhuận tốt nhất so với mật độ $2 \mathrm{con} / \mathrm{m}^{2}$ và $2,5 \mathrm{con} / \mathrm{m}^{2}$. Tuy nhiên, năng suất tôm càng xanh đạt cao nhất ở mật độ $2,5 \mathrm{con} / \mathrm{m}^{2}$. Độ mặn nước vào tháng mùa khô tăng cao ảnh hưởng đến tăng trưởng của tôm càng xanh.

Ảnh hưởng của mật độ thả tôm càng xanh giống lên hiệu quả kỹ thuật và tài chính mô hình nuôi tôm càng xanh xen canh trong ruộng lúa vùng nước lợ cần được nghiên cứu ở qui mô sản xuất với diện tích lớn hơn.

\section{LỜI CẢM TẠ}

Đề tài này được tài trợ bởi Dự án Nâng cấp Trường Đại học Cần Thơ VN14-P6 bằng nguồn vốn vay ODA từ Chính phủ Nhật Bản. Xin chân thành cảm ơn nông hộ ở xã Thới Bình, huyện Thới Bình, tỉnh Cà Mau đã hỗ trợ nhóm tác giả thực hiện đề tài.

\section{TÀI LIỆU THAM KHẢO}

Chand, B. K., Trivedi, R. K., Dubey, S. K., Rout, S. K., Beg, M. M., \& Das, U.K. (2015). Effect of salinity on survival and growth of giant freshwater prawn Macrobrachium rosenbergii (de Man). Aquaculture Reports, 2: 26-33. http://dx.doi.org/10.1016/j.aqrep.2015.05.002

Chi cục Thủy sản tỉnh Cà Mau. (2018). Báo cáo tổng kết năm 2018. https://sonnptnt.camau.gov.vn/wps/portal/dvtt/cc $\mathrm{tt} / \mathrm{ccntts}$
Dương Nhựt Long, Lam Mỹ Lan, Nguyễn Hoàng Thanh, Võ Hoàng Liêm Đức Tâm, Quách Hoàng Lê Khánh \& Nguyễn Văn Lưu. (2018). Phát triển và nâng cao hiệu quả mô hình lúa - tôm ở huyện Thới Bình tỉnh Cà Mau (báo cáo tổng kết dự án), Phòng Kinh tế và Hạ tầng huyện Thới Bình, tỉnh Cà Mau.

Dương Nhựt Long, Lam Mỹ Lan, Trần Văn Hận \& Phan Hải Đăng. (2015). Phát triển mô hình nuôi tôm càng xanh (Macrobrachium rosenbergi de Man, 1879) thâm canh trong ao đất và luân canh trong ruộng lúa ở tỉnh Hậu Giang (báo cáo kết quả dự án). Sở Khoa học và Công nghệ tỉnh Hậu Giang. https://skhcn.haugiang.gov.vn/chi-tiet//tin-tuc/Hoi-ong-anh-gia-nghiem-thu-nhiem-vukhoa-hoc-cong-nghe-nam-2015-71495

Đặng Ngọc Thanh, Hồ Thanh Hải, Dương Đức Tiến \& Mai Đình Yên. (2002). Thuý sinh học các thuý vực nước ngọt nội địa Việt Nam. Nhà xuất bản Khoa học và Kỹ thuật, Hà Nội.

Đỗ Thị Thanh Hương \& Cao Châu Minh Thư. (2012). Ảnh hưởng của nitrite lên chu kỳ lột xác và tăng trưởng của tôm càng xanh (Macrobrachium rosenbergii). Tạp chí Khoa hoc Truờng Đại học Cần Tho, 21B, 19-28.

Đỗ Thị Thanh Hương \& Nguyễn Văn Tư. (2010). Một số vấn đề về sinh lý cá và giáp xác. Nhà xuất bản Nông Nghiệp, Thành phố Hồ Chí Minh.

Đỗ Thị Thanh Hương, Nguyễn Thị Kim Hà, Bùi Văn Mướp \& Nguyễn Thanh Phương. (2014). Ảnh hưởng của $\mathrm{pH}$ lên một số chỉ tiêu sinh lý và tăng trưởng tôm càng xanh (Macrobrachium rosenbergii). Tap chi Khoa hoc Truòng Đại hoc Cần Tho; số chuyên đề Thủy sản (1), 273 - 282.

Hai, T. N, Huong, H. K., Viet, L. Q., Huong, D. T. T., \& Phuong, N. T. (2017). Giant freshwater 
prawn (Macrobrachium rosenbergii de Man, 1879) farming in brackish water areas of the Mekong Delta, Vietnam. Can Tho University Journal of Science. 7: 82-90. DOI: 10.22144/ctu.jen.2017.053

Hồ Thanh Thái. (2011). Khảo sát hiện trạng và thưc nghiệm nuôi tôm càng xanh (Macrobrachium rosenbergii) kết hợp trong ruộng lúa tại huyện Hồng Dân, tỉnh Bạc Liêu (luận văn thạc sĩ). Trường Đại học Cần Thơ.

Lam My Lan. (2006). Freshwater prawn - rice culture: the development of a sustainable system in the Mekong delta, Vietnam (doctoral dissertation). Namur University Publishing, Belgium.

New, M. B. (2002). Farming freshwater praw: a manual for the culture of the giant river prawn Macrobrachium rosenbergii. FAO Fisheries Techmical Paper, 428.

Nguyễn Thanh Phương \& Trần Ngọc Hải. (2003). Nguyên lý và kỹ thuật sản xuất giống tôm càng xanh. Nhà xuất bản Nông nghiệp, Thành phố Hồ Chí Minh.

Nguyễn Thị Thu Thủy. (2000). Kỹ thuật sản xuất giống tôm càng xanh. Nhà xuất bản Nông nghiệp, Thành phố Hồ Chí Minh.

Nguyễn Văn Hảo, Nguyễn Quang Minh \& Lâm Quyền. (2002). Một số kết quả bước đầu mô hình nuôi tôm càng xanh (Macrobrachium rosenbergii) thâm canh quy mô hộ gia đình ở Đồng bằng sông Cửu Long. Tuyển tập Nghề Cá sông Củu Long. Viện Nghiên cứu Nuôi trồng thủy sản II. 172 - 186.

Phạm Minh Tứ. (2015). Thực nghiệm mô hình nuôi tôm càng xanh (Macrobrachium rosenbergii) lúa luân canh với tôm sú (Penaeus monodon) ở tỉnh Bạc Liêu (luận văn thạc sĩ). Trường Đại học Cần Thơ.
Phạm Minh Truyền. (2003). Khảo sát các yếu tố môi trường và sinh học tôm càng xanh (Macrobrachium rosenbergii) trong mô hình tôm lúa ở Trà Vinh (luận văn thạc sĩ). Trường Đại học Cần Thơ.

Phạm Văn Tình. (2004). Kỹ thuật sản xuất giống tôm sú chất luợng cao. Nhà xuất bản Nông nghiệp Hà Nội.

Tổng cục Thủy sản. (2015, tháng 9 ngày 23). Hiện trạng và định hướng phát triển tôm-lúa tại Đồng bằng sông Cưu Long (bài báo cáo). Hội nghị "Bàn giải pháp nâng cao hiệu quả và phát triển sản xuất tôm - lúa tại Đồng bằng sông Cửu Long”, Thành phố Rạch Giá, tỉnh Kiên Giang.

Trần Tấn Huy, Tạ Văn Phương \& Dương Thị Hoàng Oanh. (2004). Thực nghiệm nuôi tôm càng xanh theo mô hình tôm lúa ở Thoại Sơn, An Giang. Tạp chi Khoa học Truòng Đại học Cần Tho, Chuyên ngành thủy sản: $230-239$.

Trần Thanh Hải. (2007). Anh hương của mật độ đến tăng trương và năng suất của tôm càng xanh (Macrobrachium rosenbergii) nuôi luân canh trên ruộng lúa tại thành phố Cần Tho (luận văn thạc sĩ). Trường Đại học Cần Thơ.

Trần Thị Thanh Hiền \& Nguyễn Anh Tuấn. (2009). Giáo trình dinh duõng và thức ăn thuỷ sản. Nhà xuất bản Nông Nghiệp.

Võ Hoàng Liêm Đức Tâm, Lam Mỹ Lan, Dương Nhựt Long, Nguyễn Thị Ngọc Anh \& Trần Ngọc Hải. (2020). Ảnh hưởng của việc sử dụng thức ăn bổ sung ương giống tôm càng xanh (Macrobrachium rosenbergii) trong ruộng lúa ở huyện Thới Bình, tỉnh Cà Mau. Tạp chí Khoa học, Truờng Đại học Cần Tho, 56 (Số chuyên đề: Thủy sản) (2): 78-86.

DOI:10.22144/ctu.jsi.2020.041 